\title{
The Effect of Calcium on Decreasing Primary Dysmenorrhea Pain Intensity: Literature Review
}

\author{
Nana Nurnaeni ${ }^{1}$,Astika Gita Ningrum ${ }^{1 *}$, Jimmy Yanuar Annas ${ }^{2}$ \\ ${ }^{1}$ Departement of Midwifery Education, Faculty of Medicine, Universitas Airlangga 60132, Surabaya, East Java- Indonesia \\ ${ }^{2}$ Departement of Obstetrics and Gynecology, Faculty of Medicine, Universitas Airlangga 60132, Surabaya, East Java - Indonesia \\ ${ }^{1}$ Email : astika.gita.n@fk.unair.ac.id
}

\begin{abstract}
Background : Women in the United States suffer a loss of 600 million, namely the loss of working hours of \$ 2 billion per year. While in Indonesia the incidence of pri is high. From the high incidence of primary dysmenorrhea, it causes a lot of losses among productive woman so that treatment is needed to overcom From several reviews of research results, it is clear that providing adequate calcium intake can reduce pain in primary dysmenorrhea. This is calcium on the incidence of primary dysmenorrhea using a literature review study. Methods : this research method uses a literature review. The last 10 years with literature searches obtained from electronic databases in the form of NCBI, PubMed and Google Scholar. Results: Five in the literature review after meeting the inclusion and exclusion criteria. Conclusion : The majority of young women still experience Intensity of primary dysmenorrhea pain is different for each individual, this can be influenced by several factors. In general, the cause of pain is due to physiological Hormonal factors. So that the problem can still be overcome and will disappear with age.
\end{abstract}

Keywords: Calcium Intake; Decreasing Primary Dysmenorrhea.

\section{Introduction}

Many women of reproductive age complain of pain during menstruation, so that many activities are disrupted. A study says that in the United States about 600 million women suffer a loss of $\$ 2$ billion per year in lost working hours, which can have a psychological and economic impact on absenteeism resulting in these losses [1]. In a systematic review and meta-analysis in Iran, the overall prevalence rate of primary dysmenorrhea was estimated to be around 71\% [2]. Thus in Indonesia the incidence of primary dysmenorrhea is around 54.89\% which occurs among women [3]. One of the research studies in Indonesia, such as research at MAN 1 Semarang, there were $65.2 \%$ of respondents who experienced dysmenorrhea every time they menstruated[4]. Likewise, in Riau Province in Kampar Regency, there were 97.5\% incidence of dysmenorrhea from three public high schools [5].

The pain of dysmenorrhea during menstruation occurs due to increased levels of prostaglandins which result in excessive muscle activity resulting in muscle wall contractions which can clog blood vessels in the myometrium and trigger pain [6]. Pain due to primary dysmenorrhea can be overcome one of them by fulfilling calcium intake. Calcium can help relieve anxiety, control the conduction of nerve impulses to the brain and from the brain deficiency calcium can cause muscle spasms [7]. Calcium intake in general can 
reduce pain during the menstrual phase and reduce water retention during the premenstrual phase. The research conducted by Jacobs also said that the results of giving calcium carbonate supplements of 1200 $\mathrm{mg} /$ day for 3 menstrual cycles in 472 women showed that $48 \%$ calcium was proven to reduce pain before menstruation [6].

\section{Method}

This research design uses a literature review study method. The literature study used is the literature of the last 10 years. Literature searches were obtained from the NCBI, PubMed and Google Scholar electronic databases. Literature screening was carried out by assessing the inclusion and exclusion criteria. The initial stage obtained 4.903 national and international articles that are considered relevant. The search for articles using the keywords "primary dysmenorrhea and calcium", "primary dysmenorrhea and adolescent" then continued at the screening stage, which in the end obtained 5 articles that matched the object to be discussed. The inclusion criteria set include : research articles on the effect of calcium administration on reducing primary dysmenorrhea pain intensity, full text, open access, publications from 2011 to 2021, articles using Indonesian and English. Likewise, the exclusion criteria include : articles in the literature review, systematic reviews.

\section{Result}

Based on the search for articles that were collected and the author's analysis, it was found that :

\begin{tabular}{|c|c|c|c|c|c|c|}
\hline Number & Author & Research Title & Country & Method & Instrument & Result \\
\hline 1 & $\begin{array}{l}\text { Ghaniy } \\
\text { Tristianti dan } \\
\text { Zulia } \\
\text { Setiyaningrum }\end{array}$ & $\begin{array}{l}\text { Peran Asupan } \\
\text { Kalsium } \\
\text { Terhadap } \\
\text { Tingkat Nyeri } \\
\text { Haid Remaja } \\
\text { Putri Ghaniy }\end{array}$ & Indonesia & $\begin{array}{l}\text { observational } \\
\text { with cross- } \\
\text { sectional } \\
\text { design }\end{array}$ & $\begin{array}{l}\text { Numerical } \\
\text { questionnaire } \\
\text { Rating Scale }\end{array}$ & $\begin{array}{l}\text { Of the } 50 \text { female } \\
\text { students, } 83 \% \\
\text { had } \\
\text { dysmenorrhea } \\
\text { with low } \\
\text { calcium intake. } \\
\text { About } 83 \% \text { or } \\
39 \text { respondents } \\
\text { experienced } \\
\text { dysmenorrhea } \\
\text { pain and as } \\
\text { many as } 17 \% \text { or } \\
8 \text { people didn't } \\
\text { experience } \\
\text { dysmenorrhea. } \\
\text { As many as } 47 \\
\text { respondents, } \\
87,2 \% \text { or } 47 \\
\text { respondents } \\
\text { lacked calcium } \\
\text { intake and } \\
12,8 \% \text { or } 6 \\
\text { respondents had }\end{array}$ \\
\hline
\end{tabular}




\begin{tabular}{|c|c|c|c|c|c|c|}
\hline & & & & & & $\begin{array}{l}\text { adequate } \\
\text { calcium intake. }\end{array}$ \\
\hline 2 & $\begin{array}{l}\text { Pinasti Utami, } \\
\text { Rucitra Afina } \\
\text { Saharani, } \\
\text { Indriastuti } \\
\text { Cahyaningsih }\end{array}$ & $\begin{array}{l}\text { Effect of } \\
\text { calcium intake } \\
\text { on reduced } \\
\text { dysmenorrhea } \\
\text { and enhanced } \\
\text { quality of life } \\
\text { among } \\
\text { university } \\
\text { students in } \\
\text { Yogyakarta }\end{array}$ & Indonesia & $\begin{array}{l}\text { quasi } \\
\text { experimental }\end{array}$ & $\begin{array}{l}\text { Visual } \\
\text { Analogue } \\
\text { Scale (VAS) } \\
\text { and Brief Pain } \\
\text { Inventory } \\
\text { (BPI) } \\
\text { questionnaire }\end{array}$ & $\begin{array}{l}\text { In the } \\
\text { assessment of } \\
\text { VAS and BPI, it } \\
\text { has a } \\
\text { significance } \\
\text { value of } 0.00 \\
\text { ( } p<\text { at } 0.05 \text { ), } \\
\text { which means } \\
\text { that the } \\
\text { administration } \\
\text { of a combination } \\
\text { of calcium is } \\
\text { effective in } \\
\text { reducing the } \\
\text { intensity of } \\
\text { dysmenorrhea } \\
\text { pain. }\end{array}$ \\
\hline 3 & $\begin{array}{l}\text { Indriastuti } \\
\text { Cahyaningsih, } \\
\text { Pinasti Utami, } \\
\text { Sri Utami }\end{array}$ & $\begin{array}{l}\text { Pemberian } \\
\text { Suplemen } \\
\text { Kombinasi } \\
\text { Kalsium, } \\
\text { Vitamin } \\
\text { B,Vitamin C } \\
\text { dan Vitamin D } \\
\text { terhadap } \\
\text { Penurunan } \\
\text { tingkat Myeri } \\
\text { Dismenore }\end{array}$ & Indonesia & $\begin{array}{l}\text { quasi } \\
\text { experimental }\end{array}$ & $\begin{array}{l}\text { Visual } \\
\text { Analogue } \\
\text { Scale (VAS) }\end{array}$ & $\begin{array}{l}\text { There was a } \\
\text { decrease in the } \\
\text { pain scale in the } \\
\text { control group } \\
\text { and the } \\
\text { treatment group } \\
\text { with a value of } \\
\text { decreased } \\
0.80 \pm 1.64 \text { and } \\
1.74 \pm 1.52 \text {, } \\
\text { respectively (p- } \\
\text { value } 0.015<\text { at } \\
0.05 \text { ). }\end{array}$ \\
\hline 4 & $\begin{array}{l}\text { Fatemeh Alsadat } \\
\text { Rahnemaei, Ali } \\
\text { Gholamrezaei, } \\
\text { Maryam } \\
\text { Afrakhteh, Farid } \\
\text { Zayeri, } \\
\text { Mohammad } \\
\text { Reza Vafa, } \\
\text { Arian Rashidi } \\
\text { and Giti Ozgoli. }\end{array}$ & $\begin{array}{l}\text { Vitamin D } \\
\text { supplementation } \\
\text { for primary } \\
\text { dysmenorrhea: } \\
\text { a double-blind, } \\
\text { randomized, } \\
\text { placebo- } \\
\text { controlled trial }\end{array}$ & Iran & $\begin{array}{l}\text { double-blind, } \\
\text { randomized }\end{array}$ & $\begin{array}{l}\text { Questionnaire } \\
\text { with } \\
\text { 11-point NRS }\end{array}$ & $\begin{array}{l}\text { Has a score } \\
(\mathrm{P}<0.001) \text { on } \\
\text { systemic } \\
\text { symptoms and } \\
\text { headache score } \\
(\mathrm{P}<0.001) \\
\text { means that } \\
\text { treatment with } \\
\text { vitamin } \\
\text { Supplementation } \\
\mathrm{D} \text { in women } \\
\text { with } \\
\text { primary } \\
\text { dysmenorrhea }\end{array}$ \\
\hline
\end{tabular}




\begin{tabular}{|c|c|c|c|c|c|c|}
\hline & & & & & & $\begin{array}{l}\text { who have a } \\
\text { vitamin D } \\
\text { deficiency } \\
\text { cannot only } \\
\text { reduce the } \\
\text { severity of pain } \\
\text { and frequency of } \\
\text { pain, it can also } \\
\text { reduce the } \\
\text { severity of } \\
\text { systemic } \\
\text { symptoms and } \\
\text { the need for pain } \\
\text { medication. }\end{array}$ \\
\hline 5 & $\begin{array}{l}\text { Devi Febriani, } \\
\text { Dewi Ariani, } \\
\text { Inggita } \\
\text { Kusumastuty }\end{array}$ & $\begin{array}{l}\text { Pengaruh } \\
\text { Konsumsi Susu } \\
\text { Sapi Terhadap } \\
\text { Penurunan } \\
\text { Intensitas Nyeri } \\
\text { Dismenore } \\
\text { Primer Pada } \\
\text { Siswi } \\
\text { Jurusan } \\
\text { Keperawatan } \\
\text { Di SMKN } 2 \\
\text { Malang }\end{array}$ & Indonesia & $\begin{array}{l}\text { true } \\
\text { eksperiment }\end{array}$ & $\begin{array}{l}\text { Questionnaire } \\
\text { NRS }\end{array}$ & $\begin{array}{l}\text { Of the three } \\
\text { treatment } \\
\text { groups, in the } \\
\text { experimental } \\
\text { group I had the } \\
\text { highest delta } \\
\text { result of } 4.57 \text {, } \\
\text { getting cow's } \\
\text { milk with } \\
\text { 1000mg calcium } \\
\text { content. The } \\
\text { results of the } \\
\text { delta with the } \\
\text { greater the value } \\
\text { of the delta } \\
\text { value, the more } \\
\text { influential it } \\
\text { means that there } \\
\text { is an influence } \\
\text { on reducing the } \\
\text { intensity of } \\
\text { primary } \\
\text { dysmenorrhea } \\
\text { pain. }\end{array}$ \\
\hline
\end{tabular}

\section{Disscusions}

Based on the search results, there are 4 articles that match the inclusion criteria. So based on the results of the review of the four articles, they are discussed in the discussion below. 


\subsection{Characteristics of Pain Level}

The average cause of primary dysmenorrhea pain in respondents is caused by early menarche. Menarche generally occurs at the age of 10-16 years before women experience a reproductive period[8]. Early menarche starting at the age of $<13$ years is a risk factor for primary dysmenorrhea. Meanwhile, the average age of the respondent's manarche was less than 15 years. Thus, in general, primary dysmenorrhea occurs starting at the age of 15-16 years, this is due to the onset of primary dysmenorrhea from 2 to 3 years after menarche. The peak of primary dysmenorrhea occurs on average in late adolescence, namely at the age of 20 years [9]. The age of menarche that is too early is significantly associated with dysmenorrhea pain, this is because the function of the reproductive organs has not developed optimally and the reproductive system is also not ready to be exposed to prostaglandins [10]. In women who experience early menarche, they will have a longer exposure to prostaglandins produced by the endometrium during menstruation.

Menstruation that has a long duration period can also be a trigger for dysmenorrhea pain. In several studies from the literature, most of the respondents had long menstrual periods [6]. In general, the duration of menstruation is around 3 to 5 days, but there are also some who experience menstruation coming out little by little on 1-2 days and some on 7 to 8 days. Menstrual duration that exceeds the normal limit or is more than 7 days can cause dysmenorrhea pain resulting from uterine contractions so that more prostaglandins are secreted. Continuous uterine contractions can also cause primary dysmenorrhea pain due to the cessation of blood supply to the uterus [6] . Likewise, the longer the duration of menstruation, the more often the uterus contracts, so that more prostaglandins are produced and primary dysmenorrhea pain arises [9].

\subsection{Calcium Effect}

Based on the 2019 RDA, adolescent girls from the age of 13 to 18 years are recommended meeting calcium as much as $1200 \mathrm{mg} /$ day. From several respondents, on average, there are still many young women who have not met their daily calcium needs. This can be caused by several factors such as body image, food selection and self-concept towards some foods, the influence of social friends, or eating habits in the family[11]. Calcium is a substance that has an important role in muscle contraction[12]. If the body's needs are not fulfilled, it is difficult for the muscles to relax or loosen up so that it can cause muscle spasms, and abdominal cramps can occur which can also result in dysmenorrhea pain [6]. By meeting sufficient calcium requirements, there can be a significant reduction in some somatic symptoms experienced during menstruation such as headaches, joint pain, some emotional disorders such as reduced appetite, depression, and sleep disorders[13]

According to Lavon Dunne in the Nutrition Almanac in 2002, in reducing pain in primary dysmenorrhea, calcium consumption is needed around 800 to $1,000 \mathrm{mg}$. The percentage of absorption at the time of consumption of calcium depends on the total amount of elemental calcium consumed at one time. The absorption of the highest amount of calcium consumption with a dose of about $500 \mathrm{mg}$. With the increasing amount of calcium intake consumed, the effectiveness of calcium absorption decreases. So if someone is taking $1,000 \mathrm{mg} /$ day of calcium from supplements, they could split the dose and take $500 \mathrm{mg}$ at two separate times. By consuming 250-500 mg every 4 hours when you feel pain [11].

\section{Conclusion}

The majority of young women still experience primary dysmenorrhea pain. The intensity of primary dysmenorrhea pain is different for each individual, this can be influenced by several factors. In general, the cause of pain is due to physiological hormonal factors. So that the problem can still be overcome and will disappear with age. 


\section{Acknowledgements}

Many thanks to the researchers, especially to the supervisors who have guided and prepared in the preparation of this article.

\section{References}

[1] R. Dmitrovic, A. R. Kunselman, and R. S. Legro, "Continuous compared with cyclic oral contraceptives for the treatment of primary dysmenorrhea: A randomized controlled trial," Obstet. Gynecol., vol. 119, no. 6, pp. 1143-1150, 2012, doi: 10.1097/AOG.0b013e318257217a.

[2] F. A. Rahnemaei et al., "Vitamin D supplementation for primary dysmenorrhea: a double-blind, randomized, placebo-controlled trial," Obstet. Gynecol. Sci., vol. 64, no. 4, pp. 353-363, 2021, doi: 10.5468/ogs.20316.

[3] A. Amalia, S. Sulistiyowati, and Y. Rumiati, "Pemanfaatan Minuman Susu Kedelai Terhadap Penurunan Disminorea Pada Remaja Putri," J. Ris. Kebidanan Indones., vol. 2, no. 2, pp. 52-61, 2018, doi: 10.32536/jrki.v2i2.25.

[4] N. H. Kojo, T. M. D. Kaunang, and A. J. M. Rattu, "Hubungan Faktor-faktor yang Berperan untuk Terjadinya Dismenore pada Remaja Putri di Era Normal Baru," e-CliniC, vol. 9, no. 2, pp. 429-436, 2021, doi: 10.35790/ecl.v9i2.34433.

[5] F. Apriyanti, E. Harmia, and R. Andriani, "HUBUNGAN STATUS GIZI DAN USIA MENARCHE DENGAN KEJADIAN DISMENORE PADA REMAJA PUTRI DI SMAN 1 BANGKINANG KOTA TAHUN 2018,” J. Matern. Kebidanan, vol. 3, no. 3, pp. 116-120, 2018.

[6] G. Tristianti and Z. Setiyaningrum, "Peran Asupan Kalsium Terhadap Tingkat Nyeri Haid Remaja Putri,” J. Ilm. Gizi dan Kesehat., vol. 2, no. 02, pp. 23-30, 2021, doi: 10.46772/jigk.v2i02.453.

[7] C. A. Anugrahhayyu, "PERBANDINGAN Dismenorea PADA PEMBERIAN KEDELAI (Glycine max) DAN KOMBINASI ASAM JAWA (Tamarindi pulpa) DENGAN KUNYIT (Curcuma domestica)," Universitas Airlangga, 2018.

[8] P. Utami, R. A. Saharani, and I. Cahyaningsih, "Pengaruh penggunaan kombinasi kalsium terhadap penurunan tingkat nyeri dismenorea dan peningkatan kualitas hidup pada mahasiswa di Yogyakarta," J. Ilm. Farm., vol. 14, no. 2, pp. 67-79, 2018, doi: 10.20885/jif.vol14.iss2.art2.

[9] T. Joshi, A. Patil, M. Kural, N. Noor, and D. Pandit, "Menstrual characteristics and prevalence of dysmenorrhea in college going girls," J. Fam. Med. Prim. Care, vol. 4, no. 3, p. 426, 2015, doi: 10.4103/2249-4863.161345.

[10] S. Charu et al., “<Menstrual-Characteristics-and-Prevalence-and-E.Pdf>,” vol. 4, no. 4, 2012.

[11] D. Febriani, D. Ariani, and I. Kusumastuty, "Pengaruh Konsumsi Susu Sapi Terhadap Penurunan Intensitas Nyeri Dismenore Primer Pada Siswi Jurusan Keperawatan Di SMKN 2 Malang,” J. Issues Midwifery, vol. 2, no. 2, pp. 20-33, 2018, doi: 10.21776/ub.joim.2018.002.02.3.

[12] I. Cahyaningsih, P. Utami, and S. Utami, "Pemberian Suplemen Kombinasi Kalsium, Vitamin B6 , Vitamin C Dan Vitamin D Terhadap Penurunan Tingkat Nyeri Dismenorea,” Media Farm. J. Ilmu Farm., vol. 15, no. 2, p. 98, 2018, doi: 10.12928/mf.v15i2.12661.

[13] A. Saeedian Kia, R. Amani, and B. Cheraghian, "The association between the risk of premenstrual syndrome and vitamin D, calcium, and magnesium status among university students: a case control study [Health Promotion Perspectives, 2015, 5(3), 225-230],” Heal. Promot. Perspect., vol. 6, no. 1, pp. 54-54, 2016, doi: 10.15171/hpp.2016.09. 